\title{
FIELD INVESTIGATION ON THE EFFICACY OF SALMONELLA VACCINE PREPARED AT BANGLADESH AGRICULTURAL UNIVERSITY
}

\author{
M. A. S. Bag, M. M. Amin, M. B. Rahman, Y. A. Arafat, M. Salim, I. H. Rasel and U. H. Majumder
}

Department of Microbiology and Hygiene, Faculty of Veterinary Science, Bangladesh Agricultural University

Mymensingh-2202, Bangladesh

\begin{abstract}
The research work was performed to investigate the immunogenicity of Salmonella vaccine produced at LPVRPC, BAU Mymensingh. The vaccination was performed at the Phenix Hatchery Ltd. Gazipur in Hy-sex brown and HY-sex white chicken designated as group A and group B respectively. Group A and B were subdivided into A1, A2, A3, B1, B2 and B3 groups containing eight birds each. Group $\mathrm{C}$ was maintained as unvaccinated control. Birds were immunized following schedule of the LPVRPC. Each bird was vaccinated SC at six weeks of age followed by a subsequent booster dose after 45 days. After four weeks of primary vaccination the mean PHA antibody titres were $96.00 \pm 34.21$ in group A1 and $96.00 \pm 34.21$ in B1 group. Prebooster vaccination the mean PHA antibody titres were 88.00 \pm 33.12 in group A2 and 88.00 \pm 33.12 in B2

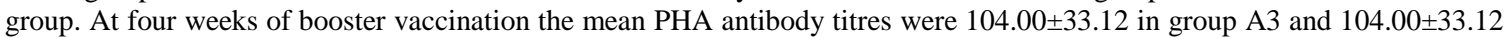
in B3 group. The mean \pm PHA antibody titre in chickens of group $\mathrm{C}$ was $\leq 4.0 \pm 0.00$. Salmonella vaccine prepared at (LPVRPC) Department of Microbiology and Hygiene, BAU induces satisfactory level of antibody in chickens determined by PHA test conducted in an on-farm study of layer chickens.
\end{abstract}

Key words: Immunogenicity, salmonella, vaccine, antibody, PHA titre

\section{INTRODUCTION}

Poultry industries in Bangladesh have been facing many constraints. Outbreak of several devastating diseases constituting major constraints is causing economic loss and discouraging poultry rearing in this country (Das et al., 2005). Surveys on both breeding flocks of commercial broiler and layer in major poultry raising belts in and around Dhaka and Gazipur districts in Bangladesh were conducted by Saleque et al. (2003) reported that the bacterial, viral mycoplasmal, protozoal, parasitic, fungal and non-infectious diseases cause $45 \%, 17 \% 12.4 \%$, $6.6 \%, 4.5 \%, 1.5 \%$ and $12.4 \%$ of total death of poultry respectively. Among the infectious diseases, prevalence of Salmonellosis was recorded as $16.9 \%$ in breeding flock (Saleque et al., 2003). Avian Salmonellosis may occur either as acute or chronic form by one or more member of genus Salmonella, under the family Enterobacteriaceae (Hofstad et al., 1984). There are mainly two types of Salmonella spp. namely S. gallinarum and S. pullorum that cause fowl typhoid and pullorum disease respectively. These two species of Salmonella are very important in poultry health because they are responsible for massive destruction. The major emphasis for preventing infections is to avoid the introduction of pathogens into the farms by enhancing bio-security (Gifford et al., 1987) along with vaccination. The vaccines available are both live (usually based on the Houghton 9R strain) and bacterins (killed/inactivated vaccine). Salmonella vaccines of both live and killed are imported and marketed in Bangladesh by different commercial companies. It is necessary to monitor purity, sterility, safety and protective efficacy of any biological or vaccines by respective controlling agency or an alternative agency prior to introducing it within the country for an extensive field use. Poultry Biologics unit (PBU) recently renamed as "Livestock and poultry Vaccine Research Development Centre (LPVRPC) incorporated with its parent organization the Department of Microbiology and Hygiene, Bangladesh Agricultural University (BAU) Mymensingh produces vaccine against $S$. pullorum and $S$. gallinarum which are distributed for field use. The vaccine is tested for its purity, safety, potency and efficacy in the laboratory and field as well.With the expansion of volume of production of vaccine it has become imperative that the vaccine be tested while being used in the farm. The present piece of research was undertaken with the following objectives: (i) Isolation and identification of Salmonella spp from infected chicken reared in farm and (ii) On farm investigation of immunogenicity of Salmonella vaccine produced by LPVRPC.

*Corresponding e-mail address: bag201@yahoo.com 


\section{MATERIALS AND METHODS Experimental design}

The present research was conducted during the period of July 2010 to December 2010 Salmonella vaccine as prepared by LPVRPC at BAU was investigated immunogenicity for measured in term of production of antibody in vaccinated chicken determined by PHA test. Five weeks aged Hy-sex chicken (white and brown) were selected for these experiment. These chicken were divided into two groups- (Vaccinated group and Unvaccinated group) under this vaccinated group collection of blood prior to vaccination from Hy-sex brown A and Hy-sex white B. Primary vaccination were done at 6 weeks of age in Hy- sex brown A and Hy-sex white B. Post primary vaccination bleeding occurred at 10 weeks of age $\left(\mathrm{A}_{1}\right.$ and $\left.\mathrm{B}_{1}\right)$ or 30 days after primary vaccination and Prebooster bleeding at 11 weeks of age $\left(\mathrm{A}_{2}\right.$ and $\left.\mathrm{B}_{2}\right)$ or 37 days after primary vaccination. Booster vaccination of Hy-sex brown A and Hy-sex white B were done at 12 weeks of age. Post booster bleeding at 16 weeks of age $\left(\mathrm{A}_{3}\right.$ and $\mathrm{B}_{3}$ ) or 74 days after primary vaccination. Then collection of sera and PHA test was performed.

\section{Passive haemagglutination (PHA) test}

The test was used to determine the antibody titers in chickens and was performed according to the methods described by Tripathy et al. (1970a), Chowdhury et al. (1987), Mondal et al. (1988), Sarker et al. (1992) Siddque et al. (1997), Supar et al. (2002), Akand et al. (2004) and Chowdhury (2008).

\section{Principle of the test}

The sensitivity of PHA test depends upon the use of soluble antigens. In this case, capsular antigens (soluble antigen) of $P$. multocida were coupled to chemically modified erythrocytes (sheep erythrocytes) and then antigen-coated erythrocytes readily react with specific antibodies and results in haemagglutination.

\section{Collection and preparation of $\mathbf{2 . 5 \%}$ horse red blood cells (HRBC)}

Blood was collected from the right jugular vein of a normal adult horse with sterilized syringe and needle containing $5 \mathrm{ml}$ of Alsever's solution for $10 \mathrm{ml}$ of blood. The collected blood was centrifuged in graduated centrifuge tube at $1500 \mathrm{rpm}$ for 10 minutes. The supernatant was then pipetted off and the blood cells were resuspended with PBS and then centrifuged. The process was repeated for at least three times for washing the blood cells. During last washing the cells were maintained in PBS up to 15 minutes and then centrifuged at 2000 rpm for 10 minutes to obtain the packed cells. After final washing, the sedimentary blood cells were diluted with PBS to make $2.5 \%$ suspension of the blood cells and preserved at 4 to $8^{\circ} \mathrm{C}$ in a refrigerator.

\section{Tannic acid treatment of horse red blood cells}

Five milliliters of $2.5 \%$ HRBC and $5 \mathrm{ml}$ of 1: 20,000 dilution of tannic acid was taken in a test tube and mixed thoroughly. The mixture was then incubated at $37^{\circ} \mathrm{C}$ for 10 to 15 minutes in water bath according to the methods of Tripathy et al. (1970a and 1970b). The cells were centrifuged at $2000 \mathrm{rpm}$ for 10 minutes; the sediment was then washed with PBS. Washed tanned HRBC was again diluted to make $2.5 \%$ suspension with PBS and used for the test.

\section{Sensitization of somatic antigen with tannic acid treated horse red blood cells}

Three $\mathrm{ml}$ of sensitized HRBC (2.5\%), $1 \mathrm{ml}$ of somatic antigen (1:10 dilution) and $8 \mathrm{~m} 1$ PBS were mixed together. This mixture was incubated at $37^{\circ} \mathrm{C}$ for 20 to 30 minutes. After sensitization, the cells were centrifuged at $1500 \mathrm{rpm}$ for 10 minutes, then the supernatant fluid was discarded and the sedimentary HRBC was collected and diluted with $1 \%$ normal rabbit serum diluents (NRSD) at the ratio of 1: 4 . This was then mixed thoroughly and kept at room temperature for an hour and centrifuged for 10 minutes. The cells were re-suspended in $1 \%$ NRSD to make $0.5 \%$ sensitized cells for use in microtitre plate method and stored at $4{ }^{\circ} \mathrm{C}$ until used (Tripathy $e t$ al., 1970a and 1970b).

\section{Microtitre plate method}

The procedure of the PHA test was followed according to the method described by Tripathy et al., (1970).An amount of $50 \mu \mathrm{l}$ of PBS was first poured in each well up to 8th well of horizontal row of microtitre plate. $50 \mu 1$ of test serum was added in the 1st well. Two fold dilutions of serum ranging from 1:2 to 1:256 were made by 
transferring $50 \mu \mathrm{l}$ of the mixture from the $1^{\text {st }}$ well to 2 nd well and thus continuing successively up to the $8^{\text {th }}$ well from where an excess amount of $50 \mu \mathrm{l}$ of the mixture was poured off. A volume of $50 \mu 10.5 \%$ somatic antigen sensitized hRBC was taken in each of the eight wells. The Control system, horizontal row of microtitre plate $\left(9^{\text {th }}\right.$ well: equal volume of $50 \mu \mathrm{l}$ of normal serum and PBS and $10^{\text {th }}$ well: equal volume of $50 \mu \mathrm{l}$ of sensitized tanned RBC and PBS). The content of the wells of the test system and control were mixed by gentle agitation of the microtitre plate and kept at room temperature for 4 to 5 hours. The PHA titre was the highest dilution of test sera were complete haemagglutination occur due to the reaction of specific antibody and antigen sensitized tanned HRBC. The results were recorded by deposition of a diffuse thin layer of clumping of RBC on the bottom of the wells, which indicated HA positive, and a compact buttoning with clear zone indicated HA negative. The reciprocal of the highest dilution of sensitized tanned HRBC was considered as titre of the serum.

\section{RESULTS}

Microplate PHA test was conducted to determine the antibody titres of test sera collected from the vaccinated and unvaccinated control chickens at different stages of this experiment and the titres are calculated and presented as mean \pm standard error. The prevaccination mean PHA antibody titre was $\leq 4.0 \pm 0.00$ in chickens of all groups. After four (4) weeks of primary vaccination $t$ he mean PHA antibody titres were $96.00 \pm 34.21$ in group $A_{1}$ and $96.00 \pm 34.21$ in group $B_{1}$. Prebooster vaccination mean PHA antibody titres were $88.00 \pm 33.12$ in group $\mathrm{A}_{2}$ and $88.00 \pm 33.12$ in group $\mathrm{B}_{2}$. After four (4) weeks of booster vaccination the mean PHA antibody titres were $104.00 \pm 33.12$ in group $A_{3}$ and $104.00 \pm 33.12$ in group $B_{3}$. The mean \pm SE PHA titre of viccnated birds are presented in the following table.

Table 1. Mean PHA titre with standard error of sera of chickens vaccinated with Salmonella vaccine prepared at BAU

\begin{tabular}{llll}
\hline Group & $\begin{array}{l}\text { Pre- vaccinated PHA titre of all vaccinated } \\
\text { and control birds }(\text { Mean } \pm \text { SE) }\end{array}$ & $\begin{array}{l}\text { Post Vaccination PHA titre of } \\
\text { vaccinate group }(\text { Mean } \pm \text { SE) }\end{array}$ & P value \\
\hline$A_{1}$ & $<4 \pm 0.00$ & $96.00 \pm 34.21$ & 0.869 \\
$A_{2}$ & $<4 \pm 0.00$ & $88.00 \pm 33.12$ & \\
$A_{3}$ & $<4 \pm 0.00$ & $104.00 \pm 33.12$ & NS \\
$B_{1}$ & $<4 \pm 0.00$ & $96.00 \pm 34.21$ & \\
$B_{2}$ & $<4 \pm 0.00$ & $88.00 \pm 33.12$ & \\
$B_{3}$ & $<4 \pm 0.00$ & $104.00 \pm 33.12$ & \\
\hline
\end{tabular}

$\mathrm{NS}=$ Statistically Not Significant, $* *$ means $\mathrm{p} \geq 0.05$

\section{DISCUSSION}

Vaccination is one of the most important methods of prevention of Salmonellosis. In Bangladesh only a good number of commercial companies import Salmonella vaccine for marketing. Such imported vaccines are used without any field trial, which should have been mandatory for testing the efficacy. It is necessary to study the immunogenicity of vaccines and to suggest the more effective schedule of vaccination. The immunogenicity was studied by the determination of the serum antibody titre by PHA test. PHA test was conducted for determination of antibody titre of the sera of vaccinated and unvaccinated chickens as per the method described by Schlink $e t$ al. (1979). The pre-vaccinated PHA titre of sera samples of all vaccinated chickens were recorded as $\leq 4 \pm 00$ (Table 7) which was closely related to the findings of Ferdous (2008). The antibody titres in this study ranges from 64 to 128 after 30 days of boostering. The lowest antibody titre was 64 and the highest antibody titre was 128. This finding is similar to Bhattacharya et al. (2004), who observed that the antibody titre induced by primary vaccination first reached to a peak and declined gradually thereafter. Rahman et al. (2005) also used rapid serum plate agglutination test and tube agglutination test to determine the antibody titre. The authors stated that antibody titres of the vaccinated birds increased quickly and reached peak four (4) weeks after vaccination.

The mean value of antibody titres of group $\mathrm{A}_{1}, \mathrm{~A}_{2}, \mathrm{~A}_{3}, \mathrm{~B}_{1}, \mathrm{~B}_{2}$ and $\mathrm{B}_{3}$ were $96.00 \pm 34.21,88.00 \pm 33.12$, $104.00 \pm 33.12,96.00 \pm 34.21,88.00 \pm 33.12,104.00 \pm 33.12$ respectively. The highest Mean \pm SE titres of was $104.00 \pm 33.12$ in group $\mathrm{A}_{3}$ at 30 days after booster vaccination and the highest Mean $\pm \mathrm{SE}$ titres of was $104.00 \pm 33.12$ in group $B_{3}$ at 30 days after booster vaccination. 
M. A. S. Bag and others

These results were in agreement with the statement of Rahman et. al., (2005), who found that the antibody titre reached peak at 4 weeks vaccination in chickens. In this present study, it was observed that in group A, the sub group $A_{3}$ produced comparatively better immune response than $A_{1}$ and $A_{2}$. In group $B$, the subgroup $B_{3}$ produced comparatively better immune response than $B_{1}$ and $B_{2}$. In group $A_{3}$ sera sample showed higher PHA titer when booster dose was given at $45^{\text {th }}$ days after primary vaccination. In group $B_{3}$ sera sample showed higher PHA titer when booster dose was given at $45^{\text {th }}$ days after primary vaccination. There were several limitations of this study such as antibody titres could not determined by ELISA. Due to short study period immune response of vaccine could not be studied through various routes. Moreover, the identified Salmonella spp (cultural, staining, biochemical test) could not be confirmed further by molecular study. Limitations which we have to consider for the different routes of vaccination could be used and different age of birds could be considered for determination of protective efficacy. As the continuation of the present study, the following research works may be undertaken in future that confirmation of Salmonella isolates at species level by molecular assays and determination of protective efficacy by using different routes of vaccination.

In conclusion, The suspected disease of chicken at Phenix Hatchery Ltd was caused by Salmonella spp. Salmonella vaccine prepared at (LPVRDC) Department of Microbiology and Hygiene, BAU, Mymensingh induces good level of antibody in chickens determine by PHA test conducted in an on farm study of layer chickens.

\section{REFERENCES}

1. Bhattacharyya DK, Rahman H and Murugkar HV (2004). Development and evaluation of Salmonella toxoid vaccine for poultry. Indian Journal Animal Science 74: 581-585.

2. Carter GR (1955). Studies on P. multocida Inhibition antibody haemagglutination test for the identification of serological types. America Journal of Veterinary Research 16: 481-484.

3. Choudhyury KA, Amin MM, Sarker AJ AH MR and Ahmed (1987). Immunization of chickens against fowl cholera with oil-adjuvanted broth culture vaccine. Bangladesh Veterinary Journal 21: 63-73.

4. Das PM, Rajib DMM, Noor M and Islam MR (2005). Retrospective analysis on the proportional incidence of poultry disease in greater Mymensingh district of Bangladesh. In: Proceeding of $4^{\text {th }}$ International Poultry Show and Seminar, from February 28 to March 2, 2003, held in Bangladesh-China Friendship Conference Centre, Agargaon, pp. 35-39.

5. Ferdous J (2008). Immunogenicity study of DLS prepared Salmonella gallinarum vaccine in comparison to commercially available one in layer chicken. M.S. Thesis submitted to the Department of Microbiology and Hygiene, Faculty of Veterinary Sciences, Bangladesh Agricultural University, Mymensingh, pp. 38- 39.

6. Gifford DH, Shane SM, Hugh JM and Weigler BJ (1987). Evaluation of biosecurity in broiler breeder. Avian Diseases 31: 339-344.

7. Hofstad-MS, Barnes-HJ, Calnek-BW, Reid-WM and Yoder HW (1984). Diseases of poultry. $8^{\text {th }}$ edition, pp. 65129.

8. Mondal SK, Choudhury KA, Amin MM, Rahman MM and Sarker AJ (1988). Immune response in chickens induced by alum precipitated fowl cholera vaccine, Humoral immune response. Bangladesh Veterinary Journal 22: 63-69.

9. Rahman MM, Khan ZUM and Rashid SMH (2005). Evaluation of the efficacy of a bacterin against Salmonella gallinarum infection. Journal Animal Veterinary Advanced 4: 332-334.

10. Saleque MA (2003). Pattern of poultry disease in breeding farms and small poultry units in Bangladesh. In: proceeding of third International Poultry Show and Seminar, held in BCFCC, Sher-e-Bangla Nagar, Dhaka, Bangladesh, pp.133-134.

11. Sarker AJ, Amin MNH and Hossain WMA (1992). Testing and quality control of poultry vaccines and its monitoring in the field. Bangladesh Agriculture University Research Programme 6: 249-257.

12. Schlink GT, and Olson LD (1979). A Microtiter Agglutination Test for Anti Salmonella gallinaru Antibodies in Turkeys. Avian Diseases 23: 1066-1071.

13. Siddique AB, Rahman MB, Amin MM and Rahman MM (1997). Antibody titres in chicks following pigeon poxvirus inoculation. Bangladesh Veterinary journal 14: 12-14. 
14. Tripathy DN, Hanson LE and Mysers WL (1970a). Passive haemagglutination test with fowl pox virus. Avian Diseases 14: 29-38.

15. Tripathy DN, Hanson LE and Mysers WL (1970b). Detection of fowl pox virus antigen in tissue culture by fluorescent antibody technique. Avian Diseases 14: 810-812. 